\title{
Salt and Ice Crystallization Resistance of Lime Mortars with Natural Lightweight Aggregate
}

\author{
Martin Vyšvařil and Patrik Bayer \\ Brno University of Technology, Faculty of Civil Engineering, Veveři 331/95, 60200 Brno, Czech \\ Republic, vysvaril.m@fce.vutbr.cz
}

\begin{abstract}
In this study, the comparison of lava sand, pumice, and natural zeolite as lightweight aggregate in air lime mortars, natural hydraulic lime mortars, and cement-lime mortars has been investigated with emphasis on the resistance of salt and ice crystallization. The lava sand and pumice improved frost resistance of the mortars while natural zeolite mortars remained without this effect due to their high water absorption. Salt crystallization resistance of the mortars was improved by using lava sand and natural pumice, while the mortars with natural zeolite were not resistant to crystallization of sodium chloride. The mortars have relatively little resistance to the reacting of $\mathrm{Na}_{2} \mathrm{SO}_{4}$, where gypsum and calcium sulfoaluminates were formed breaking the structure of the mortars. The best results were obtained using natural pumice.
\end{abstract}

Keywords: Lime Mortar, Natural Zeolite, Pumice, Lava Sand, Salt and Ice Crystallization Resistance.

\section{Introduction}

The protection of historic buildings requires the use of traditional building materials compatible with the historical ones or as close to them as possible. Air lime mortars are not suitable for use in the moist environment because of their non-hydraulic properties and low frost resistance. The use of renders made of natural hydraulic lime (NHL) is therefore often preferred for renovation purposes, although lime-cement mortars are also accepted (PachecoTorgal et al., 2012). Significant change of air lime mortars properties can be achieved by addition of pozzolanic admixtures or aggregates with pozzolanic properties. In the past, the most used ones were natural pozzolanic materials such as crushed bricks, ceramic, volcanic ash, scoria, pumice, which are still many times mentioned in conservation mortar works (Henry et al., 2012; Matias et al., 2014; Moropoulou et al., 2005; Sánchez-Moral et al., 2005; Silva et al., 2010). Porous aggregate with pozzolanic properties can improve not only the mechanical properties of mortars, but also their ability to salt accumulation from masonry, frost resistance, and liquid water transport to the mortar surface. The use of natural lightweight aggregates such as lava sand, pumice, or natural zeolite is quite common in concrete, however their utilization in lime mortars is still scarce (Barnat-Hunek et al., 2017; Ferraz et al., 2014; Lemougna et al., 2018).

In this study, the comparison of lava sand, pumice, and natural zeolite as lightweight aggregate in air lime mortars, natural hydraulic lime mortars, and cement-lime mortars has been investigated with emphasis on the resistance of salt and ice crystallization. The strength characteristics, pore structure and capillary water action of natural zeolite mortars and lava sand mortars, respectively, have already been investigated (Vyšvařil et al., 2019, Vyšvařil et al., 2019) with the conclusion that both natural aggregates positively affect the mortar strength, increase their porosity by forming coarse pores and facilitate water capillarity. 


\section{Materials and Methodology}

A commercial hydrated lime CL90-S (Čertovy Schody, Inc., Lhoist group, Tmaň, Czech Republic), a natural hydraulic lime NHL 3.5 (Zement- und Kalkwerke Otterbein GmbH \& Co. KG, Großenlüder, Germany), and a laboratory prepared blend of CL90-S and Portland cement CEM I 42.5 R (Českomoravský cement Inc., Mokrá, Czech Republic) were used as binders in prepared 3 groups of mortar mixes. Each mortars group consisted of reference samples made of quartz sand (Filtrační písky, Ltd., Chlum u Doks, CZ), and 3 types of samples with different natural lightweight aggregate $(0 / 2 \mathrm{~mm})$, fully replacing quartz sand, namely, natural zeolite (ACRE, Ltd., CZ), lava sand (Der Naturstein Garten, Hillscheid, DE), and natural pumice (Der Naturstein Garten, Hillscheid, DE). The chemical composition of all raw materials is given in Table 1. The phase compositions obtained by the X-ray diffraction analysis are presented in Table 2. Particle size distribution and loose bulk density of the aggregates are shown in author`s previous publication (Vyšvařil et al., 2019).

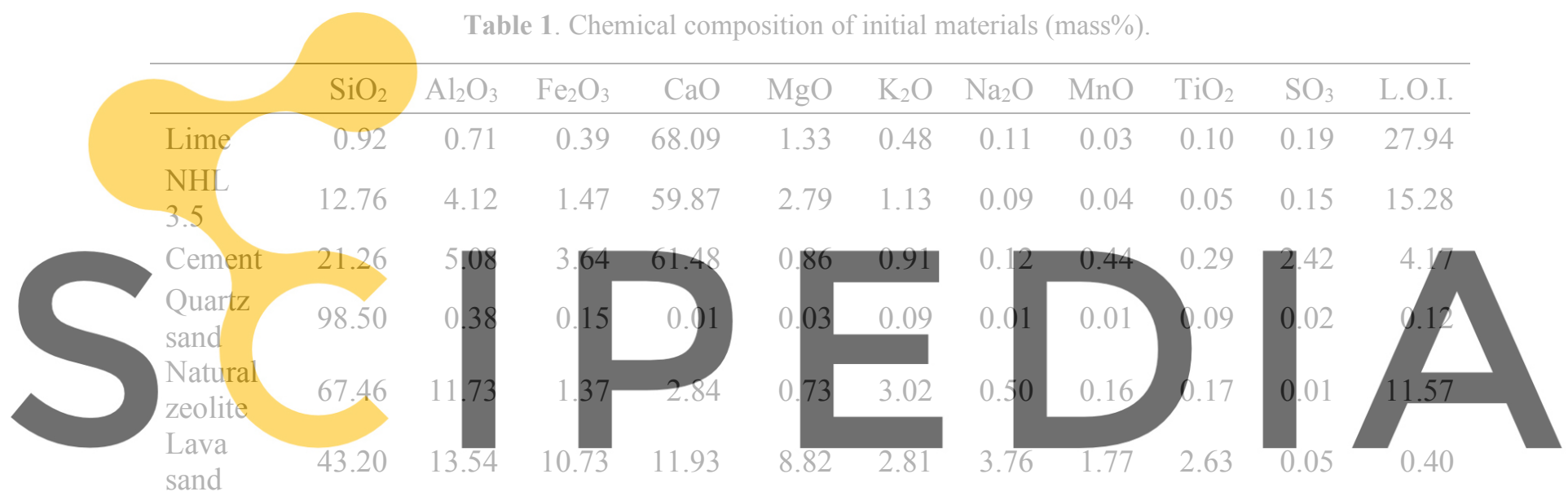

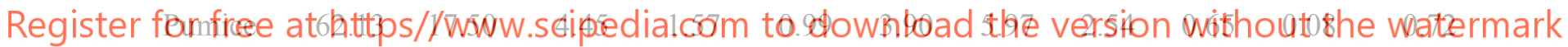

Mortar mixtures were made using the correct amount of water required to obtain a normal consistency and a good workability of the mortars $(160 \pm 5 \mathrm{~mm}$; measured by the flow table test). This consistency of lime mortars enables their easy application and good adhesion to the substrate. The proportioning of the mortar mixtures is given in Table 3. The composition of mortar mixtures considers constant binder:aggregate volume ratio of $1: 1.15$ based on a practical point of view supported by the results obtained by Lanas et al. (2003). Fresh mixtures were cast into prismatic moulds of size $40 \times 40 \times 160 \mathrm{~mm}$. Standard conditions of sample storage were $22 \pm 2{ }^{\circ} \mathrm{C}$ and relative humidity of $50 \pm 5 \%$.

The water absorption of mortars was measured according to EN 13755:2008 after curing times of $28 \mathrm{~d}$. Three mortar specimens were used to conduct the test. The total porosity of the specimens was assessed using a mercury intrusion porosimetry (MIP). Frost resistance tests were carried out according to modified Czech standard ČSN 722452. The samples were tested after 28 curing days. The total test required 15 freeze-thaw cycles. One cycle consisted of $6 \mathrm{~h}$ freezing at $-20{ }^{\circ} \mathrm{C}$ and $12 \mathrm{~h}$ thawing in a desiccator at constant relative humidity of $98 \%$ and temperature of $20{ }^{\circ} \mathrm{C}$. The frost resistance coefficient $D_{f}$ was determined as the ratio of 
flexural strength of specimens subjected to 15 freeze-thaw cycles to the flexural strength of reference specimens that did not undergo the frost resistance test. The salt crystallization resistance of mortars was determined using following solutions: $10 \% \mathrm{Na}_{2} \mathrm{SO}_{4}, 3 \% \mathrm{NaCl}$, and $3 \% \mathrm{NH}_{4} \mathrm{NO}_{3}$. The dried samples were immersed into the solutions for $7 \mathrm{~h}$ and then dried for $16.5 \mathrm{~h}$ at $60{ }^{\circ} \mathrm{C}$. The process was performed in the number of 10 cycles or till the partial disintegration of the samples. The procedure was performed according to the relevant European standard (EN 12370:1999). The state of the test specimens was monitored photographically, and detailed microstructure images were taken via a scanning electron microscope (SEM) equipped with EDX probe. The content of anions in aqueous leaches of the samples was determined by routine chemical analyses $(10 \mathrm{~g}$ of mortar sample, $500 \mathrm{ml}$ of deionized $\mathrm{H}_{2} \mathrm{O}$ ). Sulfates were set gravimetrically according to ISO 9280:1990, chlorides by mercurimetric method (ISO 5790:1979), and nitrates using Nitratax sc optical probe allowing the determination of nitrates directly in the medium.

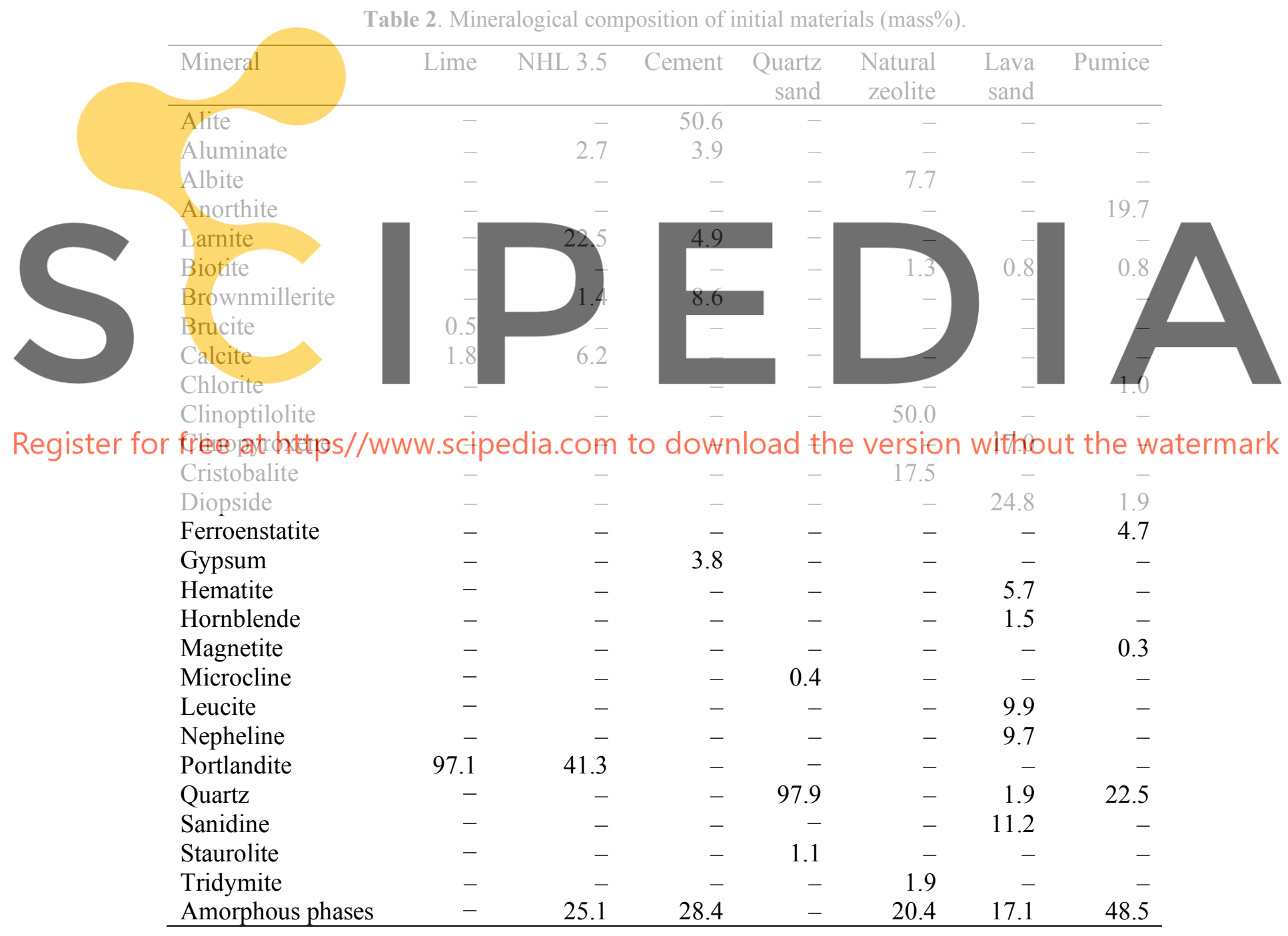


Table 3. Composition of mortar mixtures.

\begin{tabular}{lrrrrrrrr}
\hline Mixture & $\begin{array}{r}\text { Lime NHL 3.5 } \\
(\mathrm{g})\end{array}$ & $\begin{array}{r}\text { Cement } \\
(\mathrm{g})\end{array}$ & $\begin{array}{r}\text { Quartz } \\
(\mathrm{g})\end{array}$ & $\begin{array}{r}\text { Natural } \\
\text { sand }(\mathrm{g})\end{array}$ & $\begin{array}{r}\text { Lava } \\
\text { zeolite }(\mathrm{g})\end{array}$ & $\begin{array}{r}\text { Panice } \\
\text { sand }(\mathrm{g})\end{array}$ & $\begin{array}{r}\mathrm{H}_{2} \mathrm{O} \\
(\mathrm{g})\end{array}$ \\
\hline L-ref & 100 & - & - & 400 & - & - & - & 120 \\
L-NZ & 100 & - & - & - & 245 & - & - & 155 \\
L-LS & 100 & - & - & - & - & 340 & - & 115 \\
L-Pu & 100 & - & - & - & - & - & 235 & 135 \\
NHL-ref & - & 100 & - & 340 & - & - & - & 75 \\
NHL-NZ & - & 100 & - & - & 210 & - & - & 115 \\
NHL-LS & - & 100 & - & - & - & 285 & - & 80 \\
NHL-Pu & - & 100 & - & - & - & - & 200 & 105 \\
LC-ref & 50 & - & 50 & 280 & - & - & - & 70 \\
LC-NZ & 50 & - & 50 & - & 175 & - & - & 105 \\
LC-LS & 50 & - & 50 & - & - & 240 & - & 70 \\
LC-Pu & 50 & - & 50 & - & - & - & 165 & 95 \\
\hline
\end{tabular}

\section{Results and Discussion}

\subsection{Total Porosity and Water Absorption}

Since the resistance and durability of lime mortars is very dependent on their pore structure, the total porosity of the mortars (obtained by MIP) and the water absorption has beon determined before the resistance tests (Figure 1). The increasing total porosity of the mortary corresponds to the decreasing loose bulk density of the lightweight aggregate (Vyšvařil ef al., 2019), therefore the nortars with the lightest punice aggregate (-Pu) s

porosity, which can be potentially beneficial for salt and ice crystallization resistance of these mortars.

Register for free at https//www.scipedia.com to download the version without the watermark

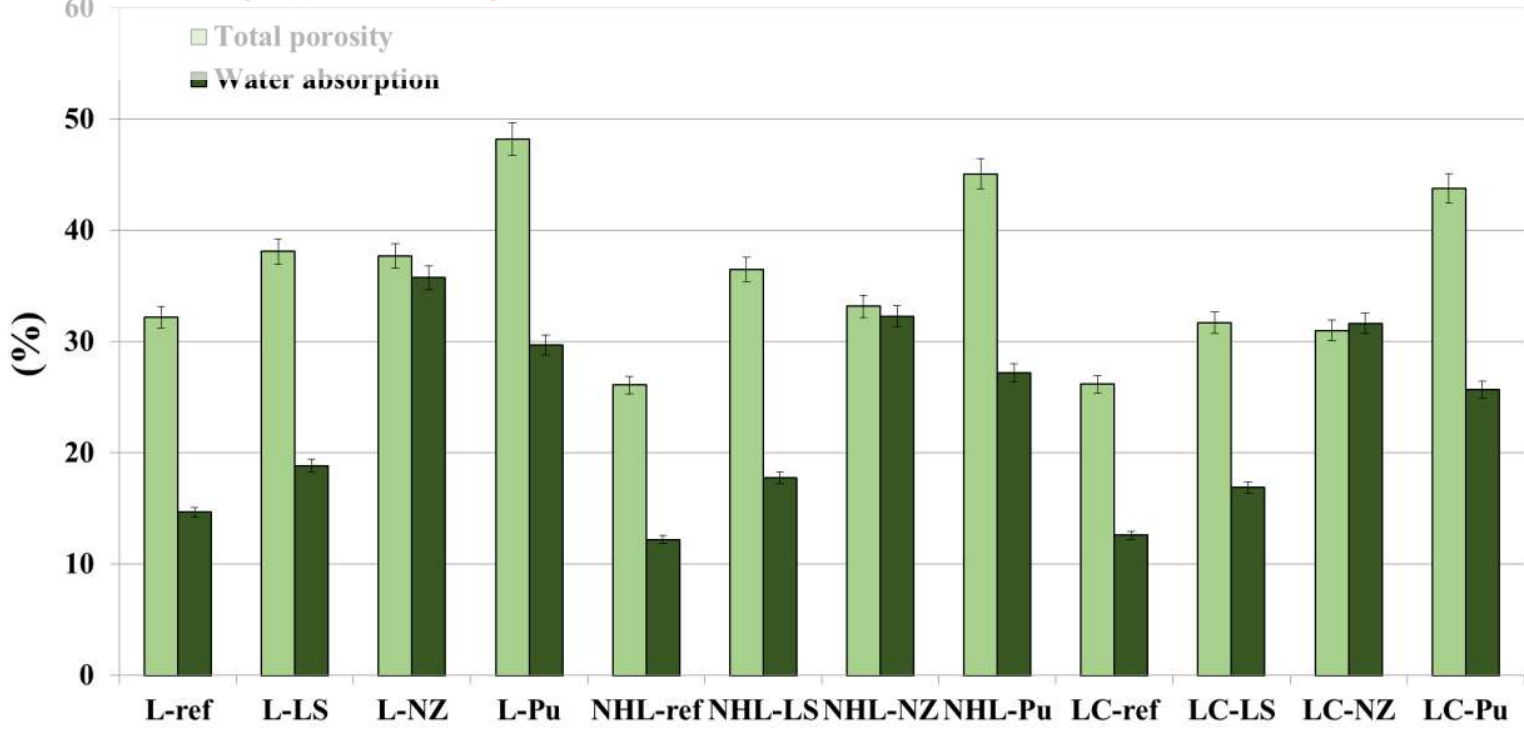

Figure 1. Total porosity and water absorption of mortar samples. 
The type of lightweight aggregate had a great influence on the water absorption of mortars. Above all, the open porous structure of the aggregate and its water-binding capacity plays an important role in water absorption, which is especially evident when using natural zeolite. This is also obvious from the high dosages of mixing water required to achieve the desired consistency of these mortars (Table 3).

\subsection{Frost Resistance}

Determination of frost resistance of mortars according to ČSN 722452 is a test of alternating freezing and thawing of water-saturated mortar beams in the number of 15 cycles. Due to the saturation of the samples with water, air lime mortars usually break up in this test before the completed 15 cycles. In this study, all tested mixtures withstood 15 freeze-thaw cycles and it was possible to determine their flexural tensile strengths and subsequently evaluate the frost resistance coefficients, $D_{f}$ (Figure 2). The frost resistance of mortars increased with increasing porosity of the samples, except for natural zeolite mortars, where the huge water-binding capacity led to a decrease in the frost resistance. Only NHL-Pu, LC-ref, LC-LS, and LC-Pu mortars exceeded the frost resistance coefficient of 0.75 and thus met the frost resistance criterion. In general, replacement of quartz sand with natural lightweight aggregate has led to a substantial improvement in the frost resistance of mortars (except natural zeolite); the best results were obtained using natural pumice.
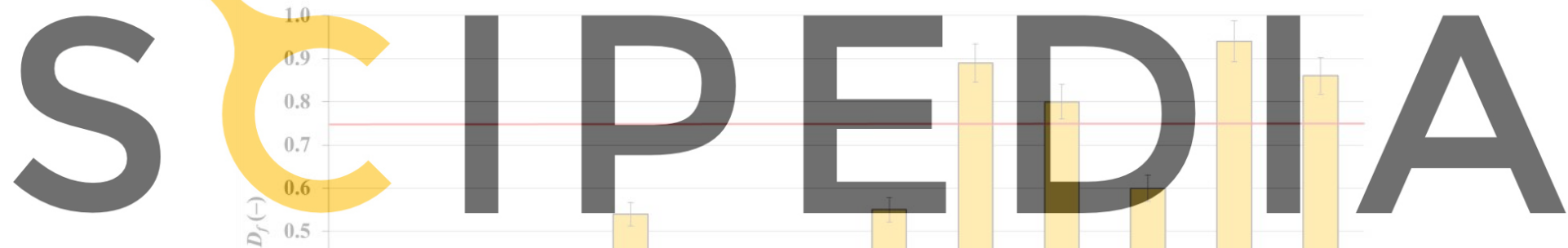

Register for free ât https//www.scipedia.com to download the version without the watermark

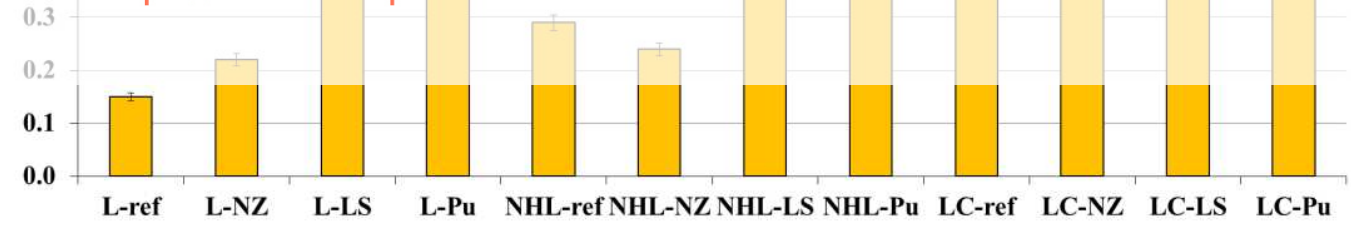

Figure 2. Frost resistance coefficient of mortar samples (red line - standard frost resistance criterion).

\subsection{Salt Crystallization Resistance}

The content of anions in aqueous leaches of the samples before and after salt crystallization resistance test is presented in Table 4 together with the sequence of the decay cycle. The results show that the concentration of the monitored anions in the samples after treatment with saline solutions increased more than 100 times; mostly in pumice samples, which also best resisted crystallization of the salts used. Thus, it has been confirmed that increased porosity is a good prerequisite for higher ability to salt accumulation and mortar resistance to salt crystallization. Table 4 shows that the mortars with NZ are not resistant to crystallization of sodium chloride. All mortar samples were also broken down after several crystallization 
cycles of sodium sulfate, where gypsum with high molar volume are formed. The NHL and LC mortars break down in the sodium sulphate solution earlier due to the presence of the aluminate phase and the formation of bulkily calcium sulfoaluminates (monosulfate and ettringite) breaking the structure of the mortar.

Table 4. Concentrations of monitored anions in aqueous leaches of mortar samples before $\left(c_{g 0}\right)$ and after $\left(c_{g}\right)$ salt crystallization resistance test, and number of test cycles to sample disintegration $(10=$ intact sample).

\begin{tabular}{|c|c|c|c|c|c|c|c|c|c|}
\hline Mixture & $\begin{array}{r}c_{g 0} \mathrm{SO}_{4}^{2-} \\
\left(\mathrm{g} \mathrm{kg}^{-1}\right)\end{array}$ & $\begin{array}{c}c_{g 0} \mathrm{Cl}^{-} \\
\left(\mathrm{g} \mathrm{kg}^{-1}\right)\end{array}$ & $\begin{array}{r}c_{g 0} \mathrm{NO}_{3}^{-} \\
\left(\mathrm{g} \mathrm{kg}^{-1}\right)\end{array}$ & $\begin{array}{c}c_{g} \mathrm{SO}_{4}^{2-} \\
\left(\mathrm{g} \mathrm{kg}^{-1}\right)\end{array}$ & $\begin{array}{r}c_{g} \mathrm{Cl}^{-} \\
\left(\mathrm{g} \mathrm{kg}^{-1}\right)\end{array}$ & $\begin{array}{l}c_{g} \mathrm{NO}_{3}^{-} \\
\left(\mathrm{g} \mathrm{kg}^{-1}\right)\end{array}$ & $\begin{array}{r}\text { Cycle } \\
\text { count in } \\
\mathrm{Na}_{2} \mathrm{SO}_{4}\end{array}$ & $\begin{array}{r}\text { Cycle } \\
\text { count in } \\
\mathrm{NaCl}\end{array}$ & $\begin{array}{r}\text { Cycle } \\
\text { count in } \\
\mathrm{NH}_{4} \mathrm{NO}_{3}\end{array}$ \\
\hline L-ref & 0.103 & 0.055 & 0.487 & 21.04 & 7.73 & 19.85 & 6 & 10 & 10 \\
\hline L-NZ & 0.083 & 0.040 & 0.323 & 36.43 & 26.20 & 32.11 & 9 & 8 & 10 \\
\hline L-LS & 0.089 & 0.054 & 0.445 & 24.88 & 22.81 & 36.18 & 7 & 10 & 10 \\
\hline $\mathrm{L}-\mathrm{Pu}$ & 0.084 & 0.099 & 0.550 & 33.57 & 31.42 & 39.38 & 8 & 10 & 10 \\
\hline NHL-ref & 0.087 & 0.049 & 0.408 & 36.44 & 9.85 & 10.43 & 4 & 10 & 10 \\
\hline NHL-NZ & 0.069 & 0.039 & 0.273 & 50.56 & 19.93 & 28.85 & 7 & 8 & 10 \\
\hline NHL-LS & 0.074 & 0.047 & 0.373 & 40.73 & 14.28 & 31.76 & 4 & 10 & 10 \\
\hline NHL-Pu & 0.063 & 0.079 & 0.466 & 44.79 & 23.64 & 38.16 & 6 & 10 & 10 \\
\hline LC-ref & 1.733 & 0.043 & 0.401 & 22.45 & 23.50 & 20.25 & 4 & 10 & 10 \\
\hline LC-NZ & 1.165 & 0.038 & 0.255 & 45.03 & 23.90 & 29.57 & 5 & 10 & 10 \\
\hline LC-LS & 0.589 & 0.040 & 0.321 & 30.78 & 26.63 & & & & \\
\hline LC-Pu & 0.658 & 0.069 & 0.440 & 36.37 & 25.39 & 41.52 & & & \\
\hline
\end{tabular}

presentation due to the largest differences between them (Figure 3). The images show that the

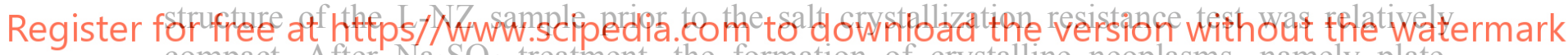

compact. After $\mathrm{Na}_{2} \mathrm{SO}_{4}$ treatment, the formation of crystalline neoplasms, namely plate-

shaped hexagonal crystals of monosulfate and needle-like ettringite, was enormous, while the

structure became more porous. Natural zeolite acted as an aluminum source for the formation of sulfoaluminate phases. Despite the higher aluminum content in the mortars with NZ aggregates compared to the reference samples and thus easier formation of the aluminate phases, the samples disintegrated later, probably due to higher porosity of these samples. In the case of $\mathrm{NH}_{4} \mathrm{NO}_{3}$, no products of relevant degradation reactions were observed in the microstructure of mortars, only calcite recrystallization occurred during each cycles of treatment, which is represented in the SEM image in the form of a large number of sharpedged calcite crystals. The structure remained relatively close. Treatment with $\mathrm{NaCl}$ solution resulted in a very porous mortar structure for both the L-NZ sample (Figure 3, d) and the NHL-NZ sample (Figure 3, e). The poor resistance of lime mortars with natural zeolite to $\mathrm{NaCl}$ crystallization is likely due to leaching of the binder from the mortar structure, since no degradation reaction products have been observed in these mortars. For comparison, the microstructure of the LC-NZ sample, which is much more compact and characterized by the presence of amorphous CSH gel and ettringite needles, is also shown in Figure 3. This sample remained intact after $\mathrm{NaCl}$ treatment. 

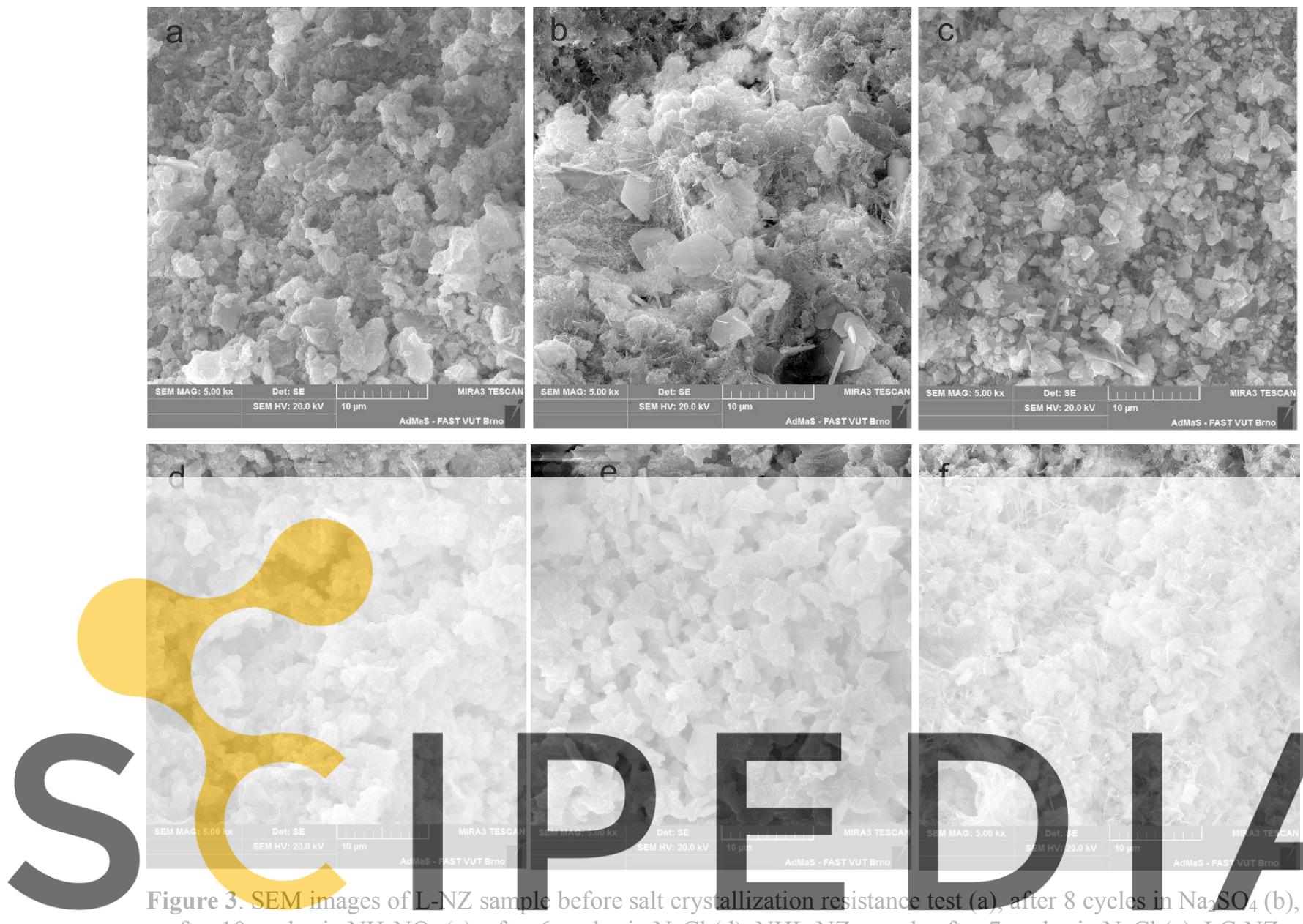

Register for free at https//www.scipedia.com to download the version without the watermark

\section{Conclusions}

- All lightweight aggregates increased the total porosity of mortars in accordance with their decreasing loose bulk density. Enhanced total porosity appears to be beneficial for salt and ice crystallization resistance of the mortars.

- Full replacement of quartz sand with natural lightweight aggregate has led to a considerable improvement in the frost resistance of mortars (except natural zeolite); the best results were obtained using natural pumice.

- Salt crystallization resistance of the mortars was improved by using lava sand and natural pumice, while the mortars with natural zeolite were not resistant to crystallization of sodium chloride. The mortars have relatively little resistance to the reacting of $\mathrm{Na}_{2} \mathrm{SO}_{4}$, where gypsum and calcium sulfoaluminates were formed breaking the structure of the mortars.

- In terms of salt and ice crystallization resistance, natural pumice seems to be the most suitable natural lightweight aggregate for lime mortars. 


\section{Acknowledgements}

This work has been financially supported by The Czech Science Foundation (GA CR) project No. 18-07332S.

\section{ORCID}

Martin Vyšvařil: https://orcid.org/0000-0002-4325-6087

Patrik Bayer: https://orcid.org/0000-0001-7866-1085

\section{References}

Barnat-Hunek, D., Siddique, R., Klimek, B. and Franus, M. (2017). The use of zeolite, lightweight aggregate and boiler slag in restoration renders. Construction and Building Materials, 142, 162-174. doi: 10.1016/j.conbuildmat.2017.03.079

ÚNM (1970). ČSN 72 2452: Testing of frost resistance of mortar. In Czech

CEN/TC 246/WG 2 (2020). EN 12370: Natural stone test methods - Determination of resistance to salt crystallisation.

CEN/TC 246/WG 2 (2008). EN 13755: Natural stone test methods - Determination of water absorption at atmospheric pressure.

Ferraz, E., Andrejkovicová, S., Velosa, A.L., Silva, A.S. and Rocha, F. (2014). Synthetic zeolite pellets incorporated to air lime--metakaolin mortars: mechanical properties. Construction and Building Materials, 69, 243-252. doi: 10.1016/j.conbuildmat.2014.07.030

Henry, A. and Stewart, J. (2012). Practical Building Conservation: Mortars Plasters and Renders. Farnham, England: Ashgate Publishing.

ISO/TC 147/SC 2 (1990). ISO 9280: Water quality - Determination of sulfate - Gravimetric method using barium chloride.

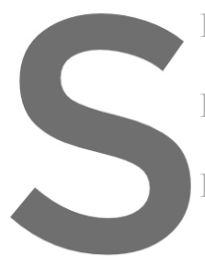

ISO/TC 47 (1979). ISO determination of chloride

Lanas, J. and Alvarez-Galinc behaviour. Cement and

Lemougna, P.N., Wang, ashes for engineering 10.1016/j.resconrec.2018.05.03
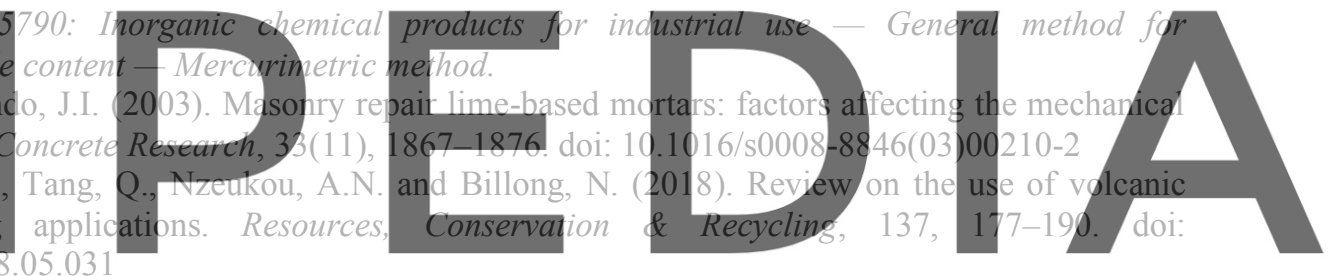

Matias, G., Faria, P. and Torres, I. (2014) Lime mortars with heat treated clays and ceramic waste: a review

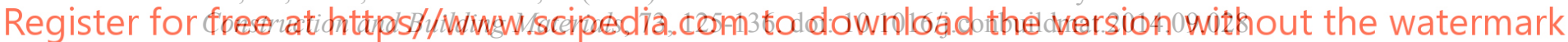

Moropoulou, A., Bakolas, A. and Anagnostopoulou, S. (2005). Composite materials in ancient structures. Cement and Concrete Composites, 27(2), 295-300. doi: 10.1016/j.cemconcomp.2004.02.018

Pacheco-Torgal, F., Faria, J. and Jalali, S. (2012). Some considerations about the use of lime-cement mortars for building conservation purpose in Portugal: a reprehensible option or a lesser evil? Construction and Building Materials, 30, 488-94. doi: 10.1016/j.conbuildmat.2011.12.003

Sánchez-Moral, S., Luque, L., Canaveras, J.-C., Soler, V., Garcia-Guinea, J. and Aparicio, A. (2005). Lime pozzolana mortars in Roman catacombs: composition, structures and restoration. Cement and Concrete Research, 35(8), 1555-1565. doi: 10.1016/j.cemconres.2004.08.009

Silva, L.M., Ribeiro, R.A., Labrincha, J.A. and Ferreira, V.M. (2010). Role of lightweight fillers on the properties of a mixed-binder mortar. Cement and Concrete Composites, 32(1), 19-24. doi: 10.1016/j.cemconcomp.2009.07.003

Vyšvařil, M., Bayer, P., Žižlavský, T. and Rovnaníková, P. (2019). Use of natural zeolite aggregate in restoration lime renders. In PRO 130: 5th Historic Mortars Conference, Paris, France, 261-272.

Vyšvařil, M., Bayer, P. and Rovnaníková, P. (2019). Use of Lava Sand as an Alternative to Standard Quartz Aggregate in Lime Mortars. Solid State Phenomena, 296, 73-78. doi: 10.4028/www.scientific.net/SSP.296.73

Vyšvařil, M., Topoláŕ, L. and Dvořák, R. (2019). Acoustic insulation properties of lime mortars with natural lightweight aggregate. MATEC Web Conf., 282, 02075. doi: 10.1051/matecconf/201928202075 